\title{
Intermittent Hypoxia Disrupts Adult Neurogenesis and Synaptic Plasticity in the Dentate Gyrus
}

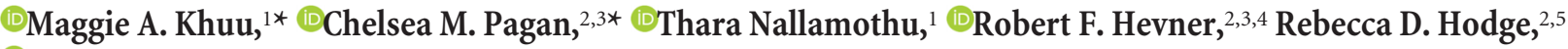 \\ () Jan-Marino Ramirez, ${ }^{2,3,4}$ and Alfredo J. Garcia III ${ }^{1}$ \\ ${ }^{1}$ Institute for Integrative Physiology, Section of Emergency Medicine, The University of Chicago, Chicago, Illinois 60637, ${ }^{2}$ Center for Integrative Brain \\ Research, Seattle Children's Research Institute, Seattle, Washington 98109, ${ }^{3}$ Departments of Pathology, ${ }^{4}$ Neurological Surgery, University of Washington, \\ Seattle, Washington 98195, and ${ }^{5}$ Allen Institute for Brain Science, Seattle, Washington 98109
}

Individuals with sleep apnea often exhibit changes in cognitive behaviors consistent with alterations in the hippocampus. It is hypothesized that adult neurogenesis in the dentate gyrus is an ongoing process that maintains normal hippocampal function in many mammalian species, including humans. However, the impact of chronic intermittent hypoxia (IH), a principal consequence of sleep apnea, on hippocampal adult neurogenesis remains unclear. Using a murine model, we examined the impact of $30 \mathrm{~d}$ of $\mathrm{IH}_{(\mathrm{IH}}\left(\mathrm{IH}_{30}\right)$ on adult neurogenesis and synaptic plasticity in the dentate gyrus. Although $\mathrm{IH}_{30}$ did not affect paired-pulse facilitation, $\mathrm{IH}_{30}$ suppressed long-term potentiation (LTP). Immunohistochemical experiments also indicate that IH perturbs multiple aspects of adult neurogenesis. $\mathrm{IH}_{30}$ increased the number of proliferating Sox $2^{+}$neural progenitor cells in the subgranular zone yet reduced the number of doublecortinpositive neurons. Consistent with these findings, cell lineage tracing revealed that $\mathrm{IH}_{30}$ increased the proportion of radial glial cells in the subgranular zone, yet decreased the proportion of adult-born neurons in the dentate gyrus. While administration of a superoxide anion scavenger during IH did not prevent neural progenitor cell proliferation, it mitigated the IH-dependent suppression of LTP and prevented adult-born neuron loss. These data demonstrate that IH causes both reactive oxygen species-dependent and reactive oxygen speciesindependent effects on adult neurogenesis and synaptic plasticity in the dentate gyrus. Our findings identify cellular and neurophysiological changes in the hippocampus that may contribute to cognitive and behavioral deficits occurring in sleep apnea.

Key words: adult neurogenesis; hypoxia

\section{Significance Statement}

Individuals with sleep apnea experience periods of intermittent hypoxia (IH) that can negatively impact many aspects of brain function. Neurons are continually generated throughout adulthood to support hippocampal physiology and behavior. This study demonstrates that IH exposure attenuates hippocampal long-term potentiation and reduces adult neurogenesis. Antioxidant treatment mitigates these effects indicating that oxidative signaling caused by IH is a significant factor that impairs synaptic plasticity and reduces adult neurogenesis in the hippocampus.

\section{Introduction}

Increased risk of neurocognitive impairment is commonly observed in sleep apnea, a predominant form of sleep-disordered breathing that afflicts both children and adults (Malhotra and White, 2002; Young et al., 2009; Sforza and Roche, 2012; Tan et al., 2013; Leng et al., 2017; Maski et al., 2017). These impairments include learning and memory deficits (Jackson et al., 2011), difficulties in attention (Beebe and Gozal, 2002), and emotional dysregulation

\footnotetext{
Received May 28, 2018; revised Sept. 3, 2018; accepted Sept. 27, 2018.

Author contributions: M.A.K., C.M.P., R.D.H., and A.J.G. designed research; M.A.K., C.M.P., T.N., and A.J.G. performed research; R.F.H., J.-M.R., and A.J.G. contributed unpublished reagents/analytic tools; M.A.K., C.M.P., T.N., and A.J.G. analyzed data; M.A.K., C.M.P., and A.J.G. wrote the paper.

${ }^{*} M . A . K$. and C.M.P. contributed equally to this work.

The authors declare no competing financial interests.
}

(Schröder and O'Hara, 2005). Although neuroimaging studies suggest that multiple brain regions are impacted by sleep apnea, the hippocampal formation is frequently identified as a site of injury in this condition (Morrell et al., 2003; Castronovo et al., 2009; Canessa et al., 2011; Torelli et al., 2011; Cha et al., 2017).

Intermittent hypoxia ( $\mathrm{IH})$ is a principal consequence of sleep apnea and has been implicated as a unique factor that may cause

This work was supported by National Institutes of Health (NIH) Grants P01-HL-094374 (J.-M.R.), R01-NS092339 (R.F.H.), and NS-085081 (R.F.H.); American Heart Association Beginning Grant-in-Aid 13BGIA1394009 (R.D.H.); and NIH Grant R01-NS-10742101 (A.J.G.). We thank A.Z. Christakis and K. Lam for assistance with immunohistochemistry.

Correspondence should be addressed to Alfredo J. Garcia at ajgarcia3@uchicago.edu.

https://doi.org/10.1523/JNEUROSCI.1359-18.2018

Copyright $\odot 2019$ the authors $\quad 0270-6474 / 19 / 391320-12 \$ 15.00 / 0$ 


\section{B Immediately post HFS}
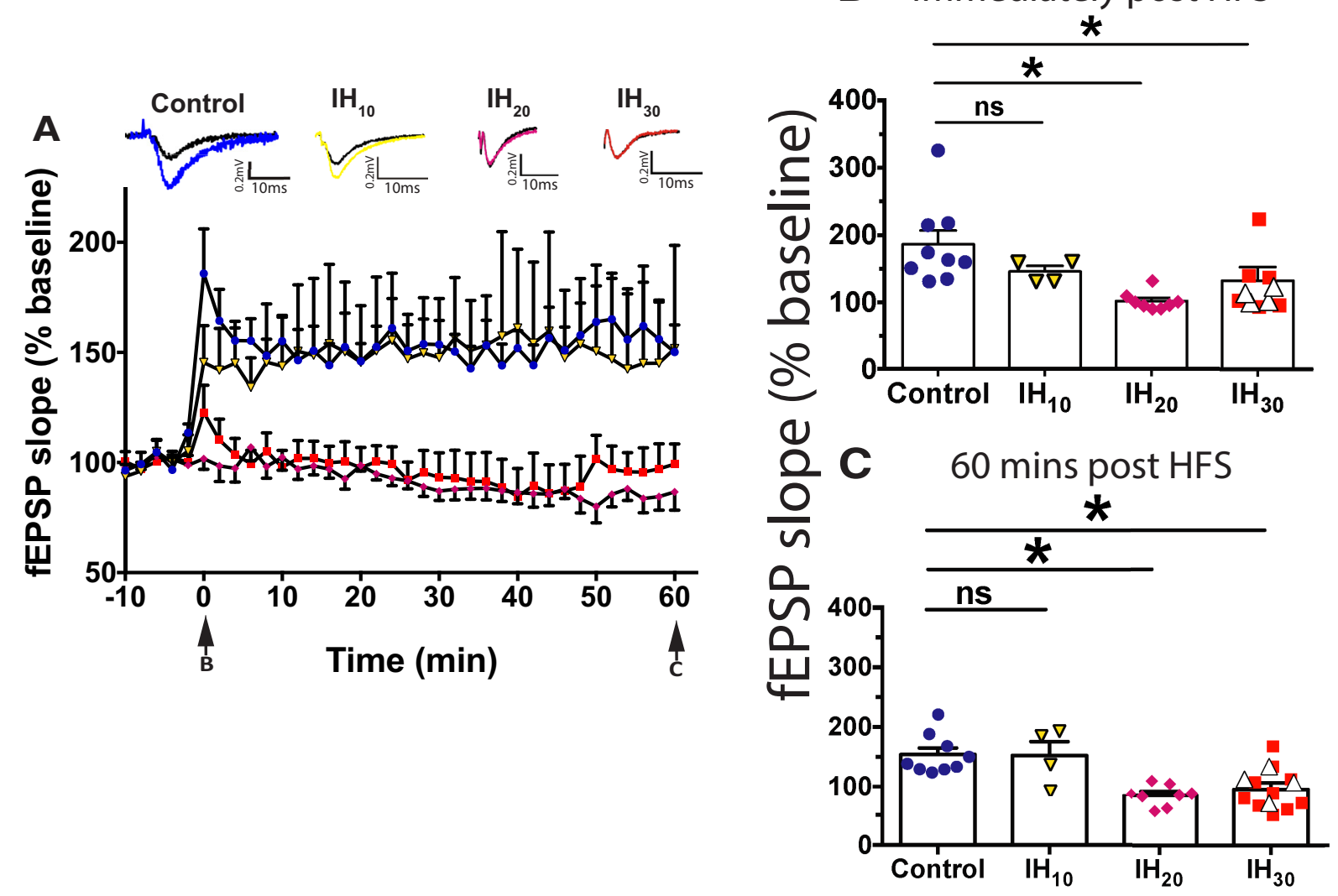

Figure 1. Prolonged IH exposure attenuates LTP within the dentate gyrus. A, LTP of the fEPSP following HFS in control (blue circles; $n=9$ slices, 7 animals), $\mathrm{HH}_{10}$ (yellow triangles; $n=4$ slices, 2 animals), $\mathrm{H}_{20}$ (magenta diamonds; $n=8$ slices, 3 animals), and $\mathrm{IH}_{30}$ (red squares; $n=10$ slices, 7 animals) illustrate differences in potentiation following HFS. Representative traces of evoked fEPSPs are shown above the graph with baseline (black trace) and post-HFS induction indicated (color traces: control, blue; $\mathbb{H}_{10}$, yellow; $I_{20}$, magenta; $\mathrm{H}_{30}$, red). Arrows at the bottom indicate the time sampled for $\boldsymbol{B}$ and $\boldsymbol{C}$. Calibration: $0.2 \mathrm{mV}, 10 \mathrm{~ms}$. $\boldsymbol{B}$, Immediately following HFS, a difference among groups was observed $\left(F_{(3,27)}=6.667, p=0.0016\right)$. A post hoc Dunnett's test revealed no difference immediately following $\mathrm{HFS}$ between control and $\mathrm{IH}_{10}$ groups, yet did in both $\mathrm{IH}_{20}$ and $\mathrm{IH}_{30}$ groups in the fEPSP slope when compared with control. C, Sixty minutes post-HFS, a difference

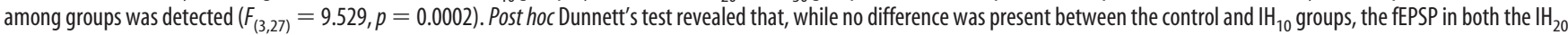
and $\mathrm{IH}_{30}$ groups was reduced compared with control group. In a subset of experiments ( $n=4$ slices, 3 animals), applying to a larger stimulation current during HFS did not to evoke LTP in the IH 30 group ( $\boldsymbol{B}$ and $\boldsymbol{C}$, white triangles). ${ }^{*} p<0.05$.

cognitive decline (Gozal et al., 2001; Polotsky et al., 2006). In rodent models, IH exposure leads to impaired spatial learning and memory, and coincides with suppressed long-term potentiation (LTP) within the CA1 region of the hippocampus. However, CA1 is only one hippocampal network that may be impacted by sleep apnea, and recent neuroimaging work suggests that this condition may alter adult neurogenesis in the dentate gyrus region of the hippocampus (Cha et al., 2017).

Adult neurogenesis uniquely supports the dentate gyrus by providing a source for cellular heterogeneity among the principal cells of this network (Schmidt-Hieber et al., 2004; Ge et al., 2007). When compared with relatively older and more mature counterparts, new adult-born granule cells are more excitable. Thus, conditions that alter hippocampal adult neurogenesis are likely to impact hippocampal neurophysiology as well (Arendt et al., 1983; Li et al., 2008; Bartesaghi et al., 2011).

Oxygenation influences adult neurogenesis (Panchision, 2009; Mazumdar et al., 2010; De Filippis and Delia, 2011; Chatzi et al., 2015). While previous investigations have reported IHmediated changes to adult neurogenesis, these studies demonstrate opposing data in regard to the generation of adult-born neurons (Gozal et al., 2003; Pedroso et al., 2016). Specifically, Gozal et al. $(2001,2003)$ show that IH increased the number of newly born neurons, while data from Pedroso et al. (2016) demon- strate a reduction in a similar population. Thus, the survival and integration of adult neurons under IH remains to be resolved.

Here, we examine how IH affects both synaptic plasticity and adult neurogenesis in the dentate gyrus of mice exposed to $30 \mathrm{~d}$ of $\mathrm{IH}\left(\mathrm{IH}_{30}\right) . \mathrm{IH}_{30}$ suppressed LTP and reduced the number of adult-born granule cells generated by adult neurogenesis. $\mathrm{IH}_{30}$ also caused an increase in neural progenitor cell proliferation in the subgranular zone (SGZ). While the administration of the superoxide anion scavenger manganese(III) tetrakis (1-methyl-4pyridyl)porphyrin (MnTMPyP) prevented both the reduction of LTP and suppression of the generation of adult-born granule cells, it did not prevent IH-dependent enhancement in cell proliferation. These findings indicate a primary role for $\mathrm{IH}$-dependent reactive oxygen species (ROS) signaling in the observed phenomena, yet IH appears to also act in a manner independent of ROS to affect processes in the dentate gyrus.

\section{Materials and Methods}

Study approval. All animal protocols were performed with the approval of the Institutional of Animal Care and Use Committee (IACUC) at Seattle Children's Research Institute or at The University of Chicago, in accordance with National Institutes of Health guidelines.

Animals. Mice were housed in AAALAC-approved facilities with a $12 \mathrm{~h}$ light/dark cycle and ad libitum access to food and water. All mice were 
maintained on a C57BL/6 background. Nestin-CreER ${ }^{\mathrm{T} 2} / \mathrm{Ai} 27 \mathrm{D}$ (Nestin-CreER ${ }^{\mathrm{T} 2}$ mice, Imayoshi et al., 2006; Ai27D mice, The Jackson Laboratory; RRID:IMSR_JAX:012567) mice were used for birth-labeling experiments.

Male and female mice [postnatal day 30 (P30) $\pm 5 \mathrm{~d}$ ] were exposed to $\mathrm{IH}$ as previously described (Garcia et al., 2016). The IH paradigm was executed during the light cycle and lasted for $8 \mathrm{~h} / \mathrm{d}$ (i.e., $80 \mathrm{IH}$ cycles/d) for $10 \mathrm{~d}$ $\left(\mathrm{IH}_{10}\right), 20 \mathrm{~d}\left(\mathrm{IH}_{20}\right)$, or $30 \mathrm{~d}\left(\mathrm{IH}_{30}\right)$. A single hypoxic cycle was achieved by flowing $100 \%$ $\mathrm{N}_{2}$ into the chamber for $\sim 60 \mathrm{~s}$, which created a hypoxic environment where the nadir $\mathrm{O}_{2}$ chamber reached $4.5 \pm 1.5 \%$ for 7 to $10 \mathrm{~s}$ and was immediately followed by an air break $\left(\sim 21 \% \mathrm{O}_{2} ; 300 \mathrm{~s}\right)$. In a subset of experiments, mice were treated daily with a cell-permeable superoxide anion scavenger, MnTMPyP (Enzo Life Sciences; $15 \mathrm{mg} / \mathrm{kg}$; http://www. enzolifesciences.com/ALX-430-070/ mntmpyp-.pentachloride/) via intraperitoneal injections throughout $\mathrm{IH}$ exposure.

Slice preparation for electrophysiology. Acute hippocampal slices were prepared from mice (P60 to P80) unexposed to IH (control) or mice exposed to $\mathrm{IH}_{10}, \mathrm{IH}_{20}$, or $\mathrm{IH}_{30}$. Tissue harvest occurred immediately following $\mathrm{IH}_{10}$ and $\mathrm{IH}_{20}$ exposure and within $5 \mathrm{~d}$ following the end of $\mathrm{IH}_{30}$ exposure. Mice were anesthetized with isoflurane and killed by rapid decapitation. The cerebrum was rapidly harvested and blocked, rinsed with cold artificial CSF (aCSF) and mounted for vibratome sectioning. The mounted brain tissue was submerged in aCSF $\left(4^{\circ} \mathrm{C}\right.$; equilibrated with $\left.95 \% \mathrm{O}_{2}, 5 \% \mathrm{CO}_{2}\right)$, and coronal corticohippocampal brain slices (450 $\mu \mathrm{m}$ thick) were prepared. Slices were immediately transferred into a holding chamber containing aCSF equilibrated with $95 \% \quad \mathrm{O}_{2}$, $5 \% \mathrm{CO}_{2}$ (at $20.5 \pm 1{ }^{\circ} \mathrm{C}$ ). Slices were allowed to recover a minimum of $1 \mathrm{~h}$ before transfer into recording chamber and were used up to $8 \mathrm{~h}$ following tissue harvest. The composition of aCSF was as follows (in mM): $118 \mathrm{NaCl}, 30 \mathrm{Glu}-$ cose, $25 \mathrm{NaHCO}_{3}, 3.0 \mathrm{KCl}, 1.5 \mathrm{CaCl}_{2}, 1.0$ $\mathrm{NaH}_{2} \mathrm{PO}_{4}$, and $1.0 \mathrm{MgCl}_{2}$. The osmolarity of aCSF was $305-315 \mathrm{mOsm}$, and when equilibrated with $95 \% \mathrm{O}_{2} / 5 \% \mathrm{CO}_{2}$, the $\mathrm{pH}$ was $7.42 \pm 2$.

Extracellular recordings of the field EPSP. The field EPSP (fEPSP) in the dentate gyrus was evoked by electrical stimulation. The stimulation electrode was positioned into the medial perforant path, and the recording electrode $(<1 \mathrm{M} \Omega)$ was placed into the molecular layer $(\mathrm{ML})$ of the dentate gyrus. The intensity of the electrical current $(100-400 \mu \mathrm{A} ; 0.1-$ 0.4 ms duration) was set to the minimum amount of current required to generate the half-maximal fEPSP [i.e., $\sim 50 \%$ of the maximal initial slope $\left(\mathrm{m}_{\mathrm{i}}\right)$ of the fEPSP]. To block potential influence by GABAergic transmission, picrotoxin $(25 \mu \mathrm{M})$ was added to the bath at $10 \mathrm{~min}$ before recordings.

To examine paired-pulse facilitation, the fEPSP was evoked every $20 \mathrm{~s}$ with interpulse intervals of ranging from 20 to $500 \mathrm{~ms}$. Paired-pulse facilitation was measured before and following tetanic stimulation. The paired-pulse ratio (PPR) at each interpulse interval was calculated according to the following equation:

$$
P P R=\frac{m_{2}}{m_{1}}
$$

where $m_{2}$ is the $m_{i}$ evoked by the second stimulus pulse, and $m_{1}$ is the $m_{i}$ evoked by the first stimulus pulse.

To examine LTP, the half-maximal fEPSP was evoked every $20 \mathrm{~s}$. After $10 \mathrm{~min}$ of recording the baseline fEPSP, LTP was induced using high- frequency stimulation (HFS). HFS consisted of four $500 \mathrm{~ms}$ trains of stimuli $(200 \mathrm{~Hz})$ given at $30 \mathrm{~s}$ intervals. Following the HFS, the fEPSP the recording continued for up to an hour. The fEPSP slope was averaged in $2 \mathrm{~min}$ windows and normalized to baseline values. All recordings were made using the Multiclamp 700B Amplifier (Molecular Devices: https://www.moleculardevices.com/systems/conventional-patch-clamp/ multiclamp-700b-microelectrode-amplifier). Acquisition and post hoc analyses were performed using the Axon pCLAMP10 software suite (Molecular Devices; https://www.moleculardevices.com/systems/axon-conventionalpatch-clamp/pclamp-11-software-suite).

Tissue processing and histological analyses. Following $\mathrm{IH}_{30}$ or normoxia exposure, mice were anesthetized with isoflurane and transcardially perfused with saline and $40 \mathrm{ml}$ of $4 \%$ paraformaldehyde according to IACUC-approved protocols. Brains were dissected and postfixed in $4 \%$ paraformaldehyde overnight. Dissected brains were then cryoprotected in $30 \%$ sucrose for a minimum of $2 \mathrm{~d}$ until equilibrated and frozen in blocks of optimum cutting temperature (OCT) medium by supercooled ethanol. Blocks containing a single hemisphere from each animal were coronally sectioned at a thickness of $40 \mu \mathrm{m}$ on a Leica cryostat, and stored in a cryoprotectant solution of primarily glycerol at $-20^{\circ} \mathrm{C}$ until time of use. Every 12th section was sampled, ensuring each animal in the study had at least three usable sections through the septal region of the dentate gyrus that contained both the suprapyramidal and infrapyrami- 
Table 1. $\mathrm{IH}_{30}$ does not affect the volume of hippocampal subregions

\begin{tabular}{lllll}
\hline Region & $\begin{array}{l}\text { Control group } \\
\left(\mathrm{mm}^{3}\right)\end{array}$ & $\begin{array}{l}\mathrm{IH}_{30} \text { group } \\
\left(\mathrm{mm}^{3}\right)\end{array}$ & $t$ value & $p$ value \\
\hline Granule cell layer & $0.171 \pm 0.022$ & $0.189 \pm 0.008$ & $t_{(3.921)}=0.765$ & 0.488 \\
Hilus & $0.212 \pm 0.031$ & $0.331 \pm 0.104$ & $t_{(5.854)}=1.090$ & 0.318 \\
Mossy fiber tract & $0.279 \pm 0.036$ & $0.324 \pm 0.020$ & $t_{(4.884)}=1.093$ & 0.325 \\
\hline
\end{tabular}

Volumes for three distinct regions [ (1) granule cell layer, (2) hilus, and (3) mossy fiber tract] were sampled and were shown to not be significantly different between the control and $\mathrm{IH}_{30}$ groups. All values are given as the mean volume \pm SEM (in $\mathrm{mm}^{3}$; Control: $n=4, \mathrm{IH}_{30}: n=6$ ).

A

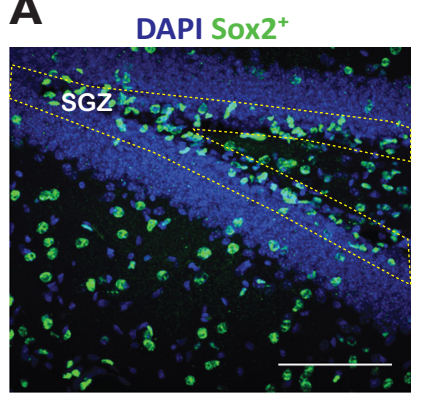

B

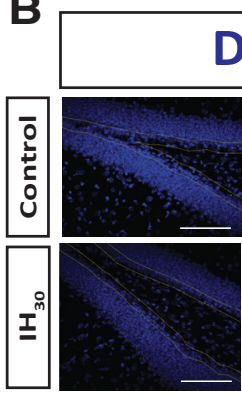

DAPI So $2^{+}$

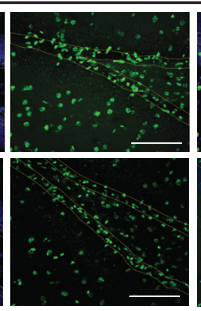

C

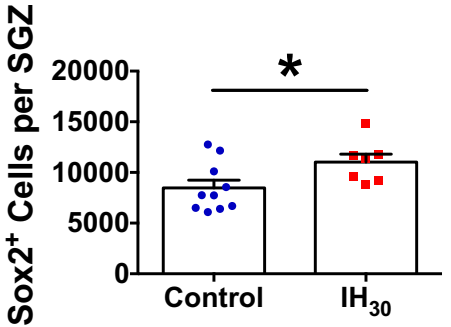

Figure 3. $\quad \mathrm{IH}_{30}$ increases the number of neural progenitor cells. $\boldsymbol{A}$, Representative section of dentate gyrus stained for Sox2 (green) and DAPI (blue). SGZ is shown outlined by yellow dotted lines. Scale bar, $100 \mu \mathrm{m}$. $\boldsymbol{B}$, Representative images of Sox2 ${ }^{+}$labeling in control (top) and $\mathrm{IH}_{30}$ (bottom) animals. SGZ is outlined in yellow. Blue channel depicts DAPI-labeled nuclei on left. Green channel depicts Sox $2^{+}$labeling in middle, and a merge is on the right. Scale bars, $100 \mu \mathrm{m}$. C, The number of Sox $2^{+}$cells in the SGZ increases following $\mathrm{IH}_{30}$ (control, $n=10 ; \mathrm{IH}_{30}, n=7 ; t_{(14.24)}=2.327$, $p=0.035)$. ${ }^{*} p<0.05$.

dal blades. Immunohistochemistry was performed on floating sections using fluorescent dye-conjugated secondary antibodies, as previously described (Hodge et al., 2008, 2012). All protocols included an overnight, $\sim 18 \mathrm{~h}$, exposure to the primary antibodies used and a $2 \mathrm{~h}$ exposure to fluorescently conjugated secondary antibodies. The primary antibodies used in the present study were rabbit anti-synaptoporin (1:500; catalog \#102002, Synaptic Systems; RRID:AB_887841), rabbit anti-Ki67 (1:100; catalog \#VP-RM04, Vector Laboratories; RRID:AB_2336545), goat antiSox2 (1:250; catalog \#sc17320, Santa Cruz Biotechnology; RRID: AB_2286684), goat anti-DCX (1:400; catalog \#sc8066, Santa Cruz Biotechnology; RRID:AB_2088494), rabbit anti-RFP (1:500; catalog \#600-401-379, Rockland; RRID:AB_2209751), and mouse anti-GFAP (1: 20,000; catalog \#MAB360, Millipore; RRID:AB_2109815). The antigen Sox 2 required additional retrieval using $0.1 \%$ citrate buffer solution before exposure to the goat anti-Sox2 primary antibody (Hodge et al., 2012).

Hippocampal volume calculations. Single-plane images of all sections containing usable dentate gyrus (defined above) were captured at low magnification [ $10 \times, 0.8$ numerical aperture (NA) air objective] on a Zeiss LSM 710 confocal microscope using Zen software. Low-magnification images of DAPI (catalog \#D9542, Sigma-Aldrich; https://www. sigmaaldrich.com/catalog/product/sigma/d9542?lang=en\&region=US) and synaptoporin, a synaptic vesicle protein enriched in the axons of dentate gyrus neurons, were used to quantify the volumes of hippocampal subregions. The granule cell layer (GCL) was determined by the area stained by DAPI, the hilus was defined as the area between the suprapyramidal and infrapyramidal blades of the dentate gyrus labeled by DAPI, and the mossy fiber tract was defined by the entire area stained with synaptoporin. All

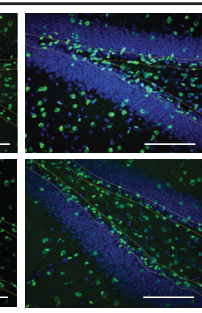

regions of interest were measured using Zen software (ZEN Digital Imaging for Light Microscopy; RRID:SCR_013672). Volumes (V) were estimated using Cavalieri's principle, $\mathrm{V}=\Sigma \mathrm{A}^{\star} \mathrm{i}{ }^{\star} \mathrm{d}$, taking the sum of aforementioned areas (A) multiplied by the interval (i) and the distance (d) between sections sampled (Rosen and Harry, 1990; Prakash et al., 1994; van Praag et al., 1999; Chatzi et al., 2015).

Immunohistochemistry quantitation. Z-stack images were obtained for all other immunohistochemical stains within the entire section of the dentate gyrus using a $40 \times, 1.3 \mathrm{NA}$ oil objective on a Zeiss LSM 710 confocal microscope with Zen software, and were quantified using ImageJ software (RRID:SCR_003070). Multiple images were required to capture the complete dentate gyrus within each usable section. The entire region of interest of the section, across multiple images, was counted. Cells intersecting the top plane of each image were excluded. Cells per dentate gyrus were estimated using Cavalieri's principal: raw counts for all imaged sections were multiplied by the interval (i) and the distance $(\mathrm{d})$ between sections sampled. For counts of doublecortin-positive $\left(\mathrm{DCX}^{+}\right)$cells, immature neurons were defined as having a cell body located in the SGZ and a radial process extending through the GCL. Examples of included and excluded cells are shown in Figure 5A. For counts of proliferating cells and of neural progenitor cells, $\mathrm{Ki}_{67}{ }^{+}$and Sox $2^{+}$counts were conducted in the SGZ, GCL, hilus, and ML regions within the dentate gyrus. The SGZ region of interest was defined as previously described in the study by Miller et al., 2013), which consisted of a two- to three-cell-thick layer between the GCL and hilus. The GCL was determined using DAPI staining, the hilus was defined as the area between the two dentate blades, excluding the overlap from the SGZ region of interest, and the molecular layer was defined as the area up to $100 \mu \mathrm{m}$ from the dentate blade.

Pulse labeling experiments were performed using Nestin-CreERT2/Ai27D mice to explicitly label a discrete cohort of neural progenitor cells. The expression of the Ai27D reporter [i.e., td-tomato, a red fluorescent protein (RFP), fused with membrane-bound channelrhodopsin2] was induced in Nestin-expressing cells using 180 mg/kg tamoxifen (catalog \#54965-24-1, Thermo Fisher Scientific; https://www.fishersci.com/shop/products/ tamoxifen-citrate-98-acros-organics-2/p-194883; dissolved in corn oil, intraperitoneal injection). Mice (between P29 and P34) received two consecutive intraperitoneal injections of tamoxifen separated by $18 \mathrm{~h}$ intervals before exposure to IH. Tissue was harvested for immunohistochemical study $30-31 \mathrm{~d}$ following the final day of tamoxifen administration. Immunostaining for RFP was used to identify cells positive for the td-tomato reporter molecule. Triple immunostaining for RFP along with glial fibrillary acid protein (GFAP) and DCX were used in combination with morphological assessment to divide birth-labeled cells into major categories: (1) $\mathrm{RFP}^{+}$neural progenitor cells; (2) $\mathrm{GFAP}^{+} / \mathrm{RFP}^{+}$astrocytes; and (3) $\mathrm{RFP}^{+}$neurons. Based on colabeling patterns, $\mathrm{RFP}^{+}$neural progenitor cells of the SGZ were further subdivided into the following: (1) $\mathrm{GFAP}^{+} / \mathrm{RFP}^{+}$progenitor cells with radial glial morphology; (2) $\mathrm{RFP}^{+}$-only neural progenitor cells; and (3) $\mathrm{RFP}^{+} / \mathrm{DCX}^{+}$neural progenitor cells. $\mathrm{GFAP}^{+} / \mathrm{RFP}^{+}$progenitor cells were distinguished from $\mathrm{GFAP}^{+} / \mathrm{RFP}^{+}$astrocytes based on morphology. $\mathrm{RFP}^{+}$-only neural progenitor cells were located in the SGZ, neither exhibited clear radial processes nor colabeled with either GFAP or DCX. $\mathrm{RFP}^{+}$-only neural progenitor cells presumably represented the pool of birth-labeled nonradial progenitors (i.e., T-box brain protein 2-positive cells) transitioning from the radial glial state but not yet expressing the $\mathrm{DCX}^{+}$phenotype of late-stage progenitor cells. In addition to colabeling, $\mathrm{RFP}^{+} / \mathrm{DCX}^{+}$ neural progenitor cells were identified as having no projections into the 
A

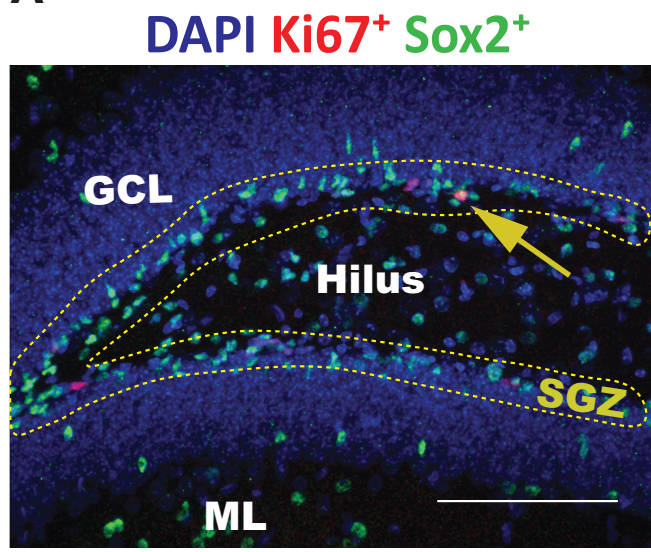

B
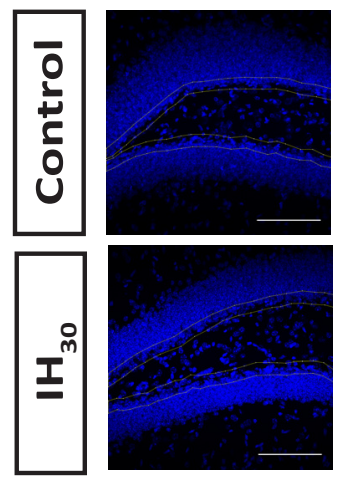
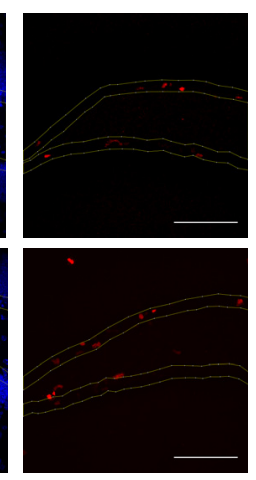

E

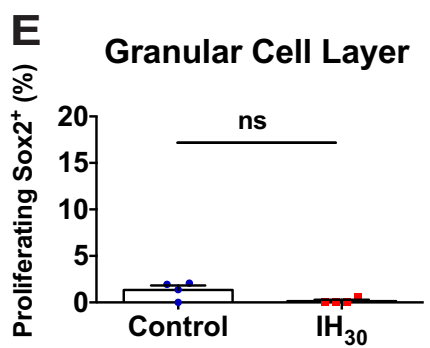

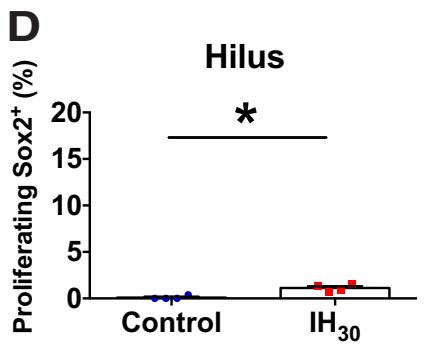
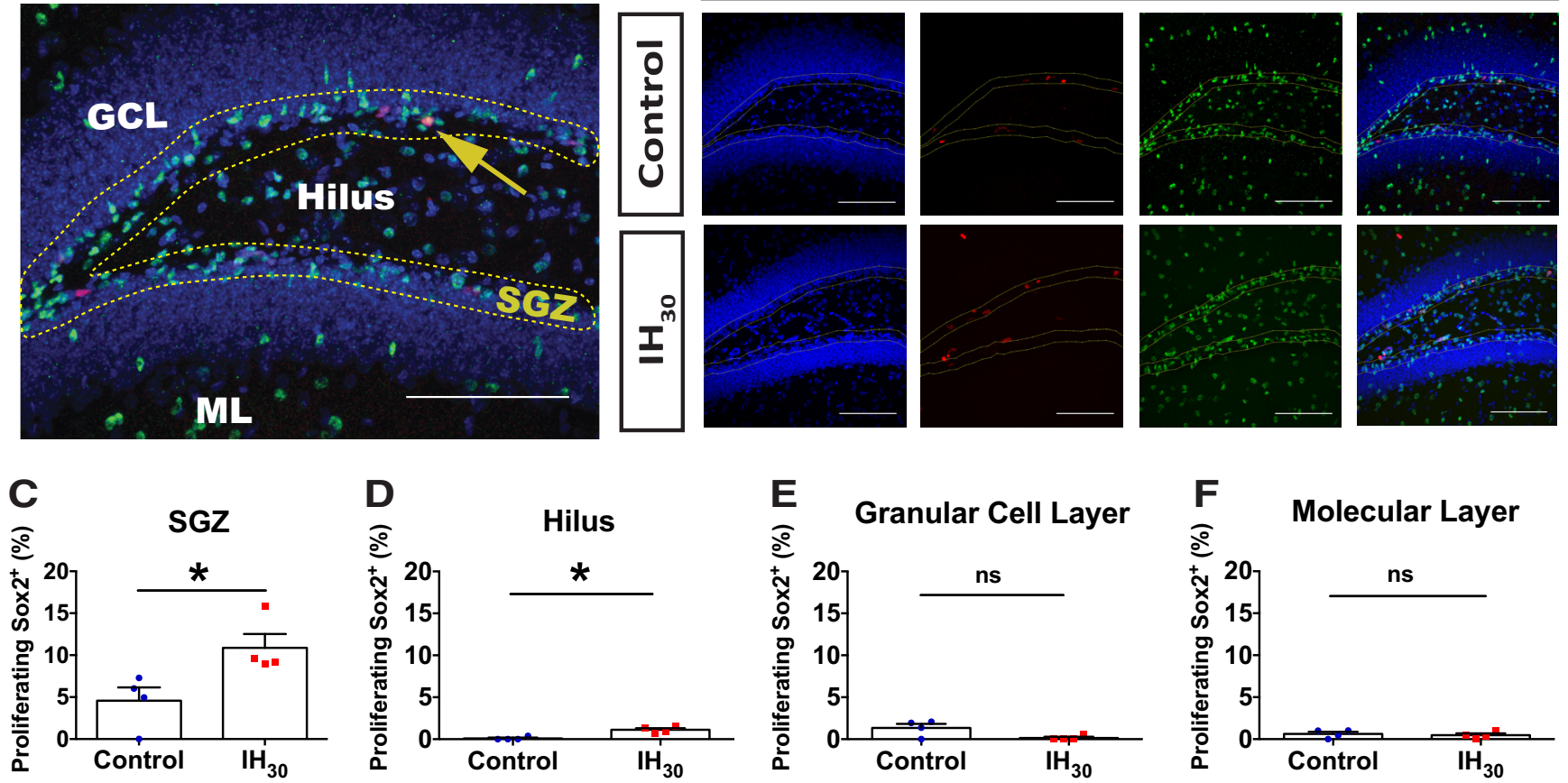

Figure 4. $\mathrm{IH}_{30}$ stimulates region-specific SOX2 ${ }^{+}$cell proliferation in the dentate gyrus. $A$, Representative section of dentate gyrus stained for Sox2 (green), Ki67 (red), and DAPI (blue). SGZ is outlined by yellow dotted lines. Counts were performed in the ML, GCL, SGZ, and hilus. The yellow arrow indicates a Ki67 ${ }^{+} / \mathrm{Sox2}{ }^{+}$double-positive cell residing within the SGZ. Scale bar, $100 \mu \mathrm{m}$. $B$, Representative images of Ki67 and Sox2 ${ }^{+}$labeling in control (top) and $\mathrm{IH}_{30}$ (bottom) animals. SGZ is outlined in yellow. Blue channel depicts DAPI-labeled nuclei on left, red channel depicts $\mathrm{Ki}_{67}{ }^{+}$labeling second from left, green channel depicts Sox2 ${ }^{+}$labeling second from right, and a merge is on the right. Scale bars, $100 \mu \mathrm{m}$. C $F$, Quantified proportions of double-labeled Sox2 ${ }^{+} / \mathrm{Ki}^{+} 7^{+}$cells $\left(\right.$control, $\left.n=4 ; \mathrm{IH}_{30}, n=4\right)$ in the SGZ $\left(t_{(5.993)}=2.747, p=0.034\right)$, hilus $\left(t_{(4.415)}=4.775, p=0.0069\right), \mathrm{GCL}\left(t_{(3.580)}=2.414, p=0.0808\right)$, and ML $\left(t_{(5.89)}=0.4592\right.$, $p=0.6625) .{ }^{*} p<0.05$.

GCL. RFP ${ }^{+}$neurons were morphologically identified as having clear dendritic projections into the GCL. Some, but not all, $\mathrm{RFP}^{+}$neurons also expressed DCX.

Sholl analysis was conducted on fully visible neurons selected from each experimental group and imaged at high magnification (100×, 1.46 NA oil objective) on a Zeiss LSM confocal microscope. Images were compressed into a maximum intensity projection in Image (NIH; Schindelin et al., 2012; Schneider et al., 2012). Using the Simple Neurite Tracer ImageJ plugin, dendritic paths of individual neurons were traced and analyzed with the Sholl analysis plugin (available in FIJI; RRID:SCR_002285; Schindelin et al., 2012). Concentric circles were drawn around the cell body in $10 \mu \mathrm{m}$ increments, and the number of neurite intersections with each circle was calculated. Intersections were plotted as a linear function of radius to serve as a measure for neurite complexity. Analysis was limited to birth-labeled neurons having at least one dendrite with a $120 \mu \mathrm{m}$ length from the soma.

Experimental design and statistical analyses. All $n$ values are the total number of animals, unless otherwise noted. Statistics were performed using Prism 6 (GraphPad Software; RRID:SCR_015807). Comparisons between two groups were conducted using unpaired two-tailed $t$ tests with Welch's correction. Comparisons between multiple groups were conducted using a one-way ANOVA with a
A
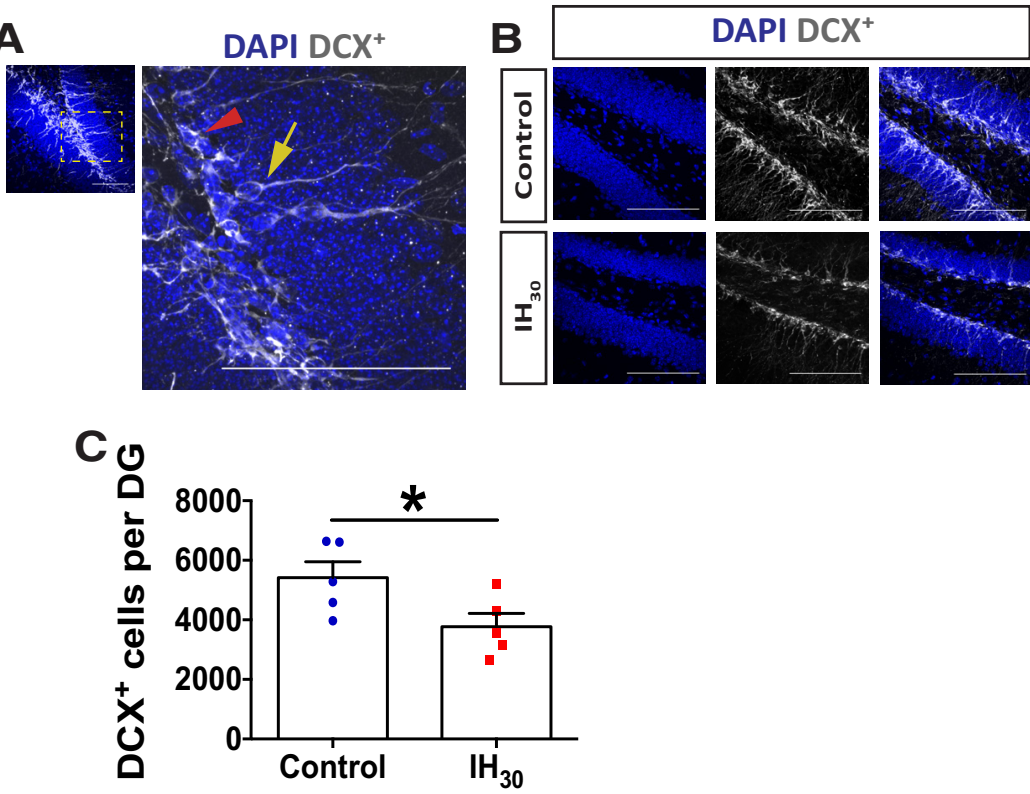

Figure 5. $\quad \mathrm{HH}_{30}$ decreases the number of newly born neurons. $A$, Representative image of $\mathrm{DCX}{ }^{+}$-labeled cells (gray) at low and high magnification. The yellow arrow shows a DCX ${ }^{+}$immature neuron that was included in the analysis based on morphology. The red arrowhead points to a $D C X^{+}$-labeled cell without a process extending into the $\mathrm{GCL}$. Scale bars, $100 \mu \mathrm{m}$. $\boldsymbol{B}$, Representative images of DCX ${ }^{+}$labeling in control (top) and $\mathrm{IH}_{30}$ (bottom) animals. Blue channel depicts DAPI-labeled nuclei on left, gray channel depicts $D C X{ }^{+}$labeling in middle, and a merge is on the right. Scale bars, $100 \mu \mathrm{m} . C, \mathrm{H}_{30}$ reduced the number of $D C X^{+}$cells with neuronal morphology exhibiting clear dendritic projections from the dentate gyrus to the molecular layer (control, $n=5 ; \mathrm{IH}_{30}$, $\left.n=5 ; t_{(7.744)}=2.368, p=0.046\right) .{ }^{*} p<0.05$. 


\section{A}
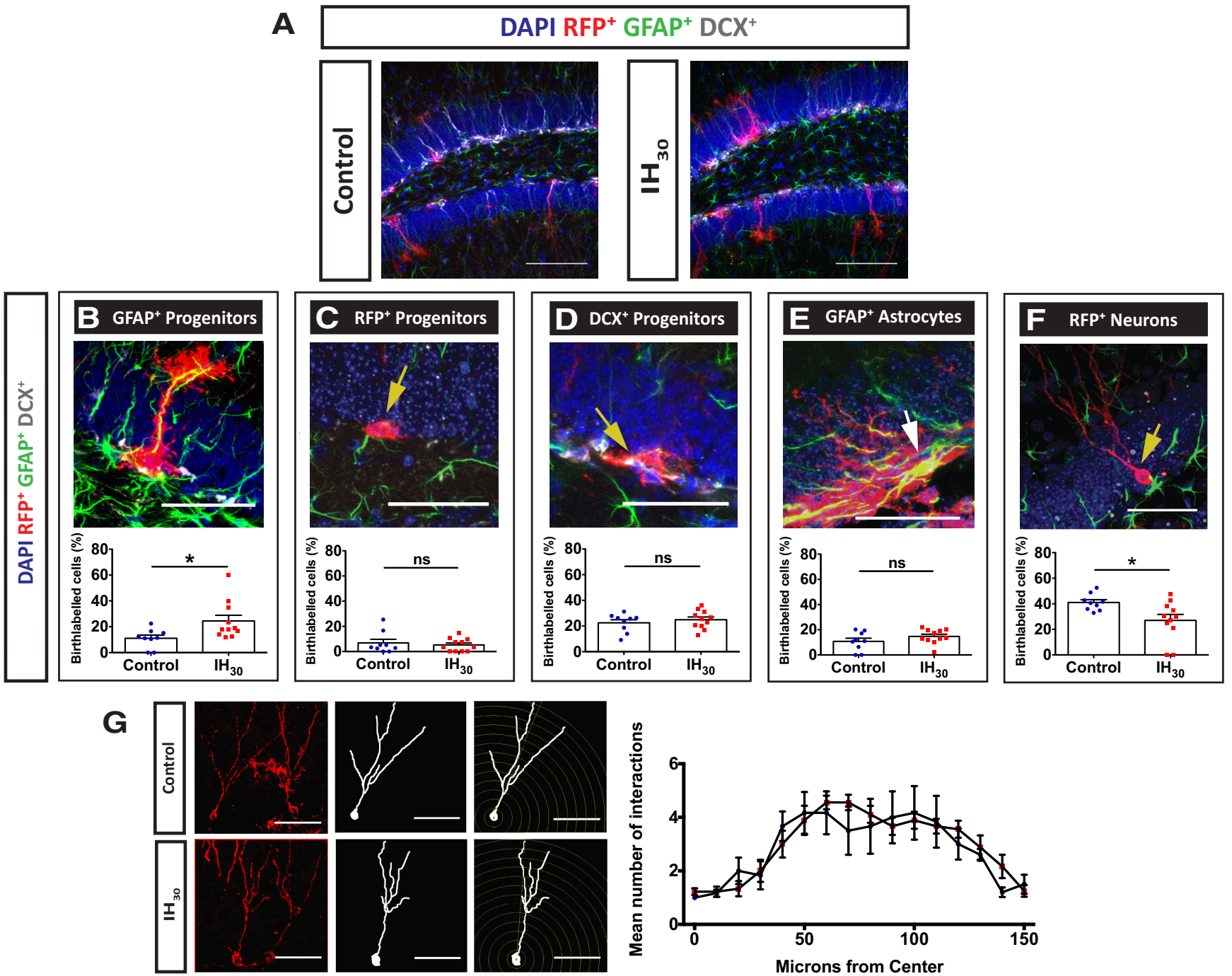

Figure 6. $\quad \mathrm{IH}_{30}$ exposure alters neural progenitor cell fate within the dentate gyrus. $A$, Representative images of tissue stained for birth-labeled RFP ${ }^{+}$cells (red), GFAP (green), DCX (gray), and DAPI (blue) from control (left) and $\mathrm{IH}_{30}$-exposed (right) mice. Scale bars, $100 \mu \mathrm{m}$. $\boldsymbol{B}-\boldsymbol{F}$, The proportion of: RFP ${ }^{+} / \mathrm{GFAP}^{+}$-colabeled cells with radial glial morphology were significantly different between groups (control, $\left.n=9 ; I_{30}, n=11 ; t_{(15.16)}=2.635, p=0.0186 ; \boldsymbol{B}\right) ; \mathrm{RFP}^{+}$neural progenitor cells in the SGZ were unchanged between groups $\left(\right.$control, $n=8 ; \mathrm{IH}_{30}, n=11 ; t_{(12.60)}=$ $0.4915, p=0.6315 ; C ; \operatorname{RFP}^{+} / \mathrm{DCX}^{+}$-colabeled progenitor cells were unchanged between groups (control, $\left.n=8 ; \mathrm{IH}_{30}, n=11 ; t_{(17.13)}=0.7422, p=0.4680 ; \boldsymbol{D}\right) ; \mathrm{RFP}^{+} / \mathrm{GFAP}^{+}$-colabeled cells with astrocytic morphology were not significantly different between the two groups (control, $n=8 ; \mathrm{IH}_{30}, n=11 ; t_{(14.68)}=1.267, p=0.2250 ; \boldsymbol{E}$ ); RFP ${ }^{+}$cells that exhibit neuronal morphology were reduced in $\mathrm{IH}_{30}$ mice (control, $n=8 ; \mathrm{IH}_{30}, n=11 ; t_{(13.97)}=2.730, p=0.0163 ; \boldsymbol{F}$ ). Scale bars: $\boldsymbol{B}-\boldsymbol{F}, 50 \mu \mathrm{m}$. $\mathbf{G}$, Sholl analysis revealed that there were no significant changes in morphology as characterized by the number of intersections in dendritic arborization (control, $n=7 ; \mathrm{H}_{30}, n=10 ; F_{(30,320)}=0.750, p=0.828$ ). Representative images of neurons from control (top) and I $\mathrm{H}_{30}$ (bottom) used for analysis on left. Scale bars: $50 \mu \mathrm{m} .{ }^{*} p<0.05$.

post hoc Dunnett's test. The equality of variances between two groups was determined with an $F$ test. Sholl analysis was completed using a two-way ANOVA of means. Data are presented as individual data points overlaid on the mean \pm SEM. Significance was defined as ${ }^{\star} p<0.05$. Analyses that were not statistically significant were defined as "n.s."

\section{Results}

Duration-dependent and targeted influence of IH on synaptic plasticity in the dentate gyrus

We sought to compare how LTP in the dentate gyrus was affected following $\mathrm{IH}_{10}, \mathrm{IH}_{20}$, and $\mathrm{IH}_{30}$. During baseline conditions, there was very little fluctuation in the evoked fEPSP in all groups suggesting that submaximal basal synaptic transmission was similar among control and the IH groups before HFS (Fig. $1 A$; control: $n=9$ slices, 7 animals; $\mathrm{IH}_{10}: n=4$ slices, 2 animals; $\mathrm{IH}_{20}: n=8$ slices, 3 animals; $\mathrm{IH}_{30}: n=10$ slices, 7 animals). LTP was induced by HFS in slices from control (i.e., $0 \mathrm{~d} \mathrm{IH}$ ) and $\mathrm{IH}_{10}$ groups but was suppressed in slices following $\mathrm{IH}_{20}$ and $\mathrm{IH}_{30}$ (Fig. $1 \mathrm{~A}$ ). Im- mediately following HFS, the fEPSP was potentiated in control and $\mathrm{IH}_{10}$ groups, yet suppressed in both the $\mathrm{IH}_{20}$ and $\mathrm{IH}_{30}$ groups (Fig. 1B). While potentiation of the fEPSP continued for up to 60 min post-HFS induction in the control and $\mathrm{IH}_{10}$ groups, no potentiation was evident in the majority of slices from $\mathrm{IH}_{20}$ and $\mathrm{IH}_{30}$ (Fig. 1C). In a subset of experiments, we used a larger stimulus current in an attempt to induce LTP in slices following $\mathrm{IH}_{30}$ yet was unsuccessful in inducing LTP (Fig. $1 B, C$, white triangles; $n=$ 4 slices, 3 animals). To further determine whether suppressed LTP coincided with changes in presynaptic release probability, we compared the paired-pulse profiles of the fEPSP in slices from the control and $\mathrm{IH}_{30}$ groups across a range of interpulse intervals (Fig. 2A). PPRs were similar between groups at all interpulse intervals examined, suggesting that the presynaptic medial perforant pathway was unaffected by $\mathrm{IH}_{30}$ (Fig. 2B). Additionally, no differences in the PPR were observed before and following tetanic stimulation (Fig. $2 C$; control: $n=6$ slices, 3 animals; $\mathrm{IH}_{30}: n=8$ 

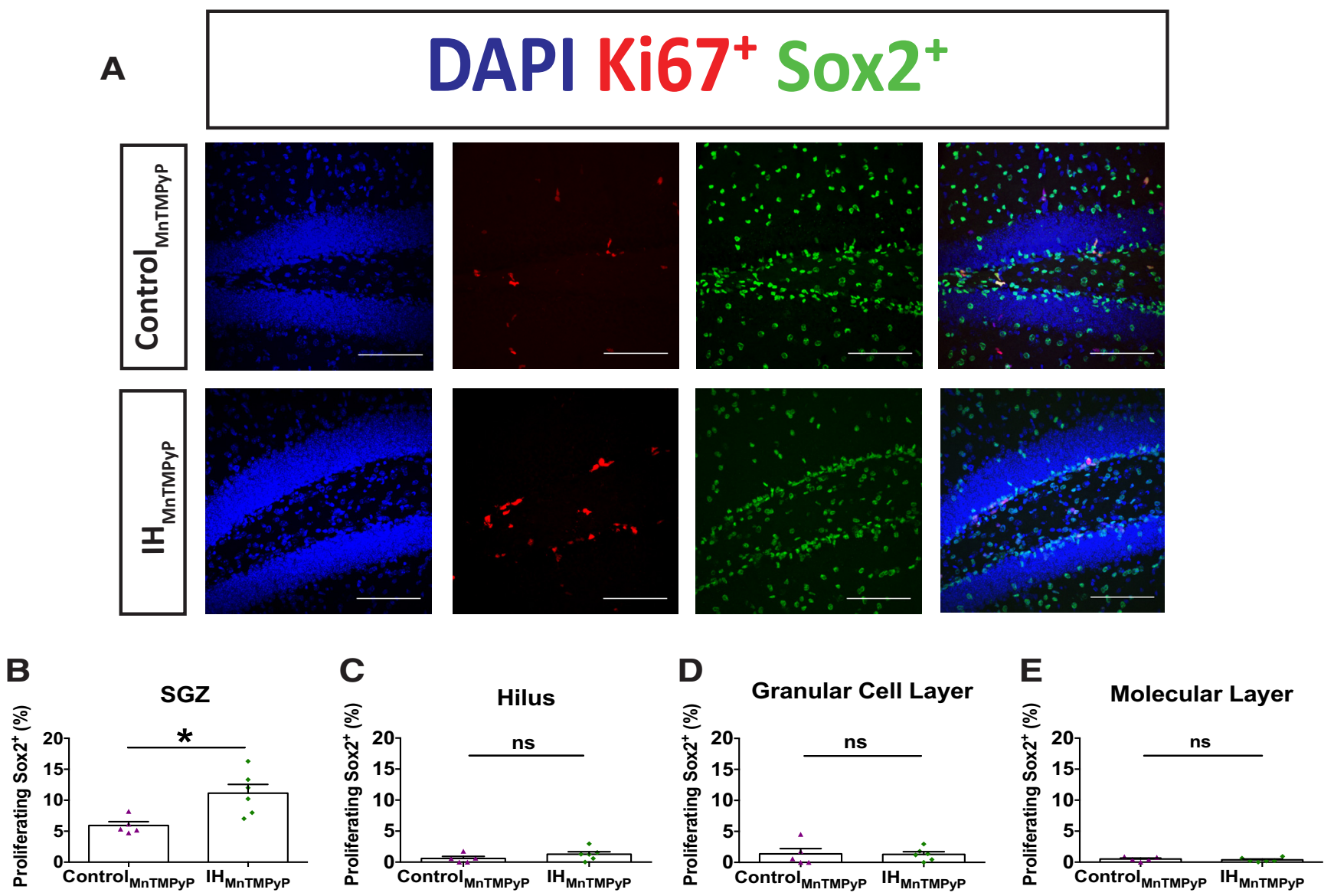

Figure 7. MnTMPyP administration reveals that neural progenitor cell proliferation is ROS independent. $\boldsymbol{A}$, Representative images of Ki67 and Sox2 ${ }^{+}$labeling in control MnTMPyP $_{\text {(top) and }}$ $\mathrm{IH}_{\text {MnTMPyP }}$ (bottom) animals are shown. Blue channel depicts DAPI-labeled nuclei on left, red channel depicts Ki67 ${ }^{+}$labeling second from left, green channel depicts Sox2 ${ }^{+}$labeling second from right, and a merge is on the right. Scale bars, $100 \mu \mathrm{m} . \boldsymbol{B}-\boldsymbol{E}$, The proportion of Ki67 ${ }^{+} / \mathrm{Sox} 2^{+}$-colabeled cells (control ${ }_{\text {MnTMPyp }}, n=5 ; \mathrm{IH}_{\text {MnTMPyp }}, n=6$ ) was increased following $\mathrm{IH}_{\text {MnTMPyP }}$ in the SGZ $\left(t_{(6.773)}=3.390, p=0.0122 ; \boldsymbol{B}\right)$, yet no differences were observed in the hilus $\left(t_{(8.869)}=1.293, p=0.2287 ; \boldsymbol{C}\right), \mathrm{GCL}\left(t_{(5.953)}=0.0863, p=0.9340 ; \boldsymbol{D}\right)$, and $\mathrm{ML}\left(t_{(8.532)}=0.6589, p=0.5273 ; \boldsymbol{E}\right)$. ${ }^{*} p<0.05$.

slices, 3 animals). These findings indicate that IH-mediated changes to synaptic plasticity not only are duration dependent, but also target postsynaptic plasticity without significant changes to presynaptic release probability before and following HFS. IH has been reported to cause apoptotic activity throughout the hippocampal formation (Yuan et al., 2015), which could affect LTP and grossly impact anatomical structures within the dentate gyrus. Therefore, we compared general anatomical structures in the dentate gyrus and surrounding regions between control and $\mathrm{IH}_{30}$ groups for histological evidence of anatomical differences between control and $\mathrm{IH}_{30}$ groups. The volume of DAPI staining in the granule cell layer was similar between groups, suggesting that $\mathrm{IH}_{30}$ did not cause gross changes in volumes of the GCL or hilus (Table 1). Similarly, no differences were observed in the volume of the hilus or synaptoporin staining volume in the mossy fiber tract between groups (Table 1 ).

$\mathrm{IH}_{30}$ differentially impacts neural progenitor cell number and new neuron generation in the hippocampus

Hippocampal synaptic plasticity is influenced by changes in adult neurogenesis (Snyder et al., 2001; Bruel-Jungerman et al., 2005; Tashiro et al., 2007; Gu et al., 2012b; Park et al., 2015), and our macroscopic observations could not discount the possibility that $\mathrm{IH}_{30}$ perturbed this process. We examined the Sox2-positive $\left(\right.$ Sox $2^{+}$) neural progenitor cell population throughout the SGZ to assess how the early stages of neurogenesis are affected by $\mathrm{IH}_{30}$. Neural cells of the SGZ were identified by Sox $2^{+}$labeling (Fig. $3 A$; control, $\left.n=10 ; \mathrm{IH}_{30}, n=7\right) . \mathrm{IH}_{30}$ appeared to increase the Sox $2^{+}$neural progenitor cells (Fig. $3 B$ ). Relative to control, there was a $30 \%$ increase following $\mathrm{IH}_{30}$ (Fig. 3 C).

We sought to determine whether the increased Sox $2^{+}$population in the SGZ reflected an increase in proliferation by coimmunolabeling Sox 2 and the mitotic marker Ki67 (Fig. $4 A ; n=4$ animals/group). Sox $2^{+} / \mathrm{Ki} 7^{+}$cells in the SGZ increased following $\mathrm{IH}_{30}$ when compared with control (Fig. 4B). Under control conditions, $6.1 \pm 0.7 \%$ of the Sox $2^{+}$population was colabeled with $\mathrm{Ki}_{6}{ }^{+}$; whereas following $\mathrm{IH}_{30}, 9.2 \pm 0.2 \%$ of the Sox ${ }^{+}$ population colabeled with $\mathrm{Ki}^{+} 7^{+}$. This represented an approximate $50 \%$ increase in the Sox $2^{+} / \mathrm{Ki}_{6} 7^{+}$population following $\mathrm{IH}_{30}$ (Fig. $4 \mathrm{C}$ ). Since Sox 2 is also expressed in non-neural progenitor cells (e.g., glia) outside of the SGZ (Komitova and Eriksson, 2004; Brazel et al., 2005), we tested whether $\mathrm{IH}_{30}$ stimulated the proliferation of $\mathrm{SOX}{ }^{+}$cells outside the SGZ . Similar to the SGZ, SOX $2^{+} / \mathrm{KI}_{6}{ }^{+}$colabeling in the hilus was increased following $\mathrm{IH}_{30}$, increasing the percentage of proliferating cells from $<0.96 \pm 0.96 \%$ in the control group to $1.20 \pm$ $0.20 \%$ in the $\mathrm{IH}_{30}$ group (Fig. $4 D$ ). In contrast to the SGZ and hilus, no colabeling differences were observed between groups for the GCL (Fig. 4E) and the ML (Fig. 4F). These data indicate that $\mathrm{IH}_{30}$ causes regional-specific increases in SOX2 ${ }^{+}$cell proliferation within the SGZ and hilus. 
A
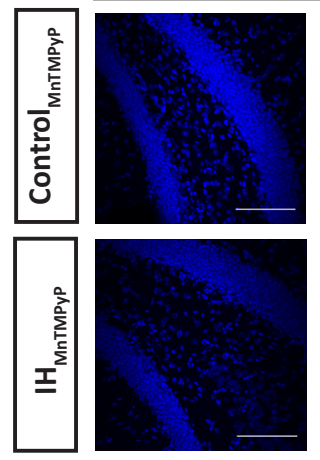

\section{c}
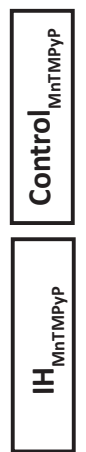
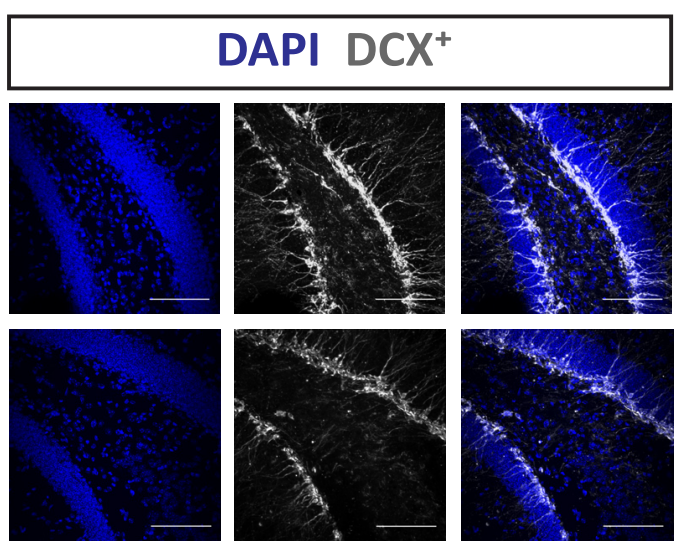

DAPI RFP ${ }^{+}$
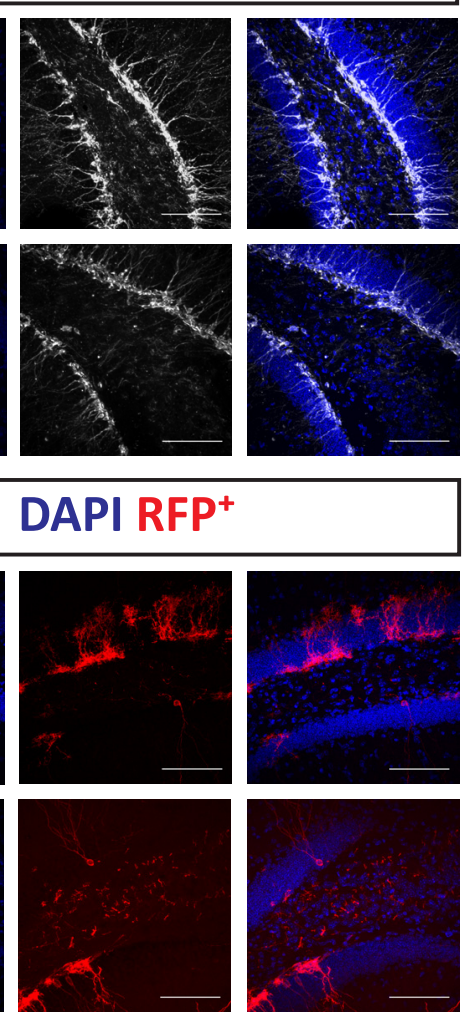

B

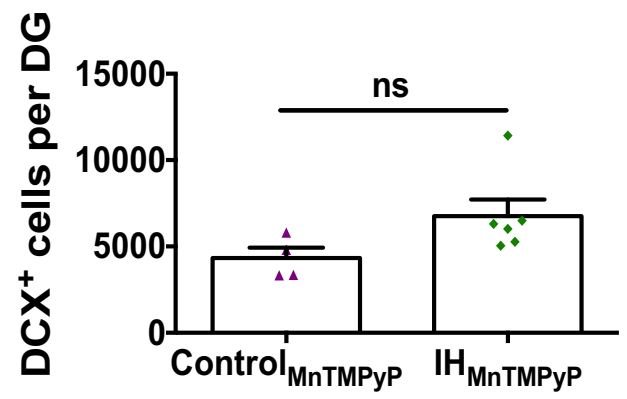

D

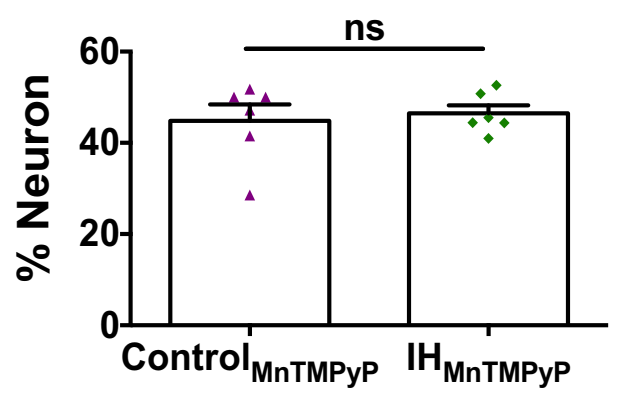

Figure 8. MnTMPyP administration reveals that neuron development is ROS dependent. $\boldsymbol{A}$, Representative images of DCX ${ }^{+}$labeling in control $_{\text {MnTMPyP }}$ (top) and I $\mathrm{H}_{\text {MnTMPyP }}$ (bottom) animals are shown. Blue channel depicts DAPI-labeled nuclei on left, gray channel depicts DCX ${ }^{+}$labeling in middle, and a merge is on the right. Scale bars, $100 \mu \mathrm{m}$. $\boldsymbol{B}$, Immature granule neurons labeled with $\mathrm{DCX}^{+}$showed no significant difference between $\mathrm{IH}_{\text {MnTMPyP }}$ and control $\mathrm{MnTMPyP}_{\text {Proups (control }}$ MnTMPyP,$\left.n=4 ; \mathrm{IH}_{\text {MnTMPyP}}, n=6 ; t_{(7.708)}=2.144, p=0.066\right)$. C, Representative images of RFP ${ }^{+}$

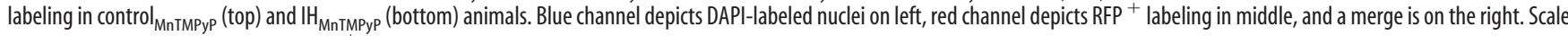
bars, $100 \mu \mathrm{m}$. D. The percentages of RFP ${ }^{+}$neurons were not different between $\mathrm{IH}_{\text {MnTMPyP }}$ and control $\mathrm{MnTMPyP}_{\text {groups }}\left(\right.$ control $\left._{\text {MnTMPyP }}, n=6 ; \mathrm{IH}_{\mathrm{MnTMPyP}}, n=6 ; t_{(7.361)}=0.402, p=0.699\right)$.

To assess how IH influences the latter stages of adult neurogenesis, we examined how $\mathrm{IH}_{30}$ affected the number of immature neurons as indicated by positive doublecortin labeling (i.e., $\mathrm{DCX}^{+}$) with dendritic projections into the GCL, under $\mathrm{IH}_{30}$ or control conditions (Fig. $5 A$; control: $n=5 ; \mathrm{IH}_{30}: n=5$ ). $\mathrm{DCX}^{+}$ neural progenitor cells, which lack dendritic projections, were not included in this analysis. $\mathrm{DCX}^{+}$-labeled immature neurons decreased following $\mathrm{IH}_{30}$ (Fig. $5 B$ ). Following $\mathrm{IH}_{30}$, the number of $\mathrm{DCX}^{+}$immature neurons was reduced by $30.4 \%$ when compared with control (Fig. $5 C$ ). These results suggest that $\mathrm{IH}$ causes a defect in the maturation from neural progenitor cell to neuron.

$\mathrm{IH}_{30}$-dependent changes to the neural progenitor cell fate in the SGZ were assessed through birth-labeling experiments (Fig. $6 \mathrm{~A}$; control group, $n=9$; $\mathrm{IH}_{30}$ group, $n=11$ ). Consistent with our observations with $\mathrm{SOX} 2{ }^{+}$cells in the $\mathrm{SGZ}, \mathrm{IH}_{30}$ increased in the percentage of $\mathrm{GFAP}^{+} / \mathrm{RFP}^{+}$cells with radial glial morphology when compared with control (Fig. 6B; control, $11.11 \pm$ $\left.2.43 \% ; \mathrm{IH}_{30}, 24.48 \pm 4.45 \%\right)$. However, the percentage of $\mathrm{RFP}^{+}$only progenitor cells (Fig. $6 C$ ) and $\mathrm{DCX}^{+} / \mathrm{RFP}^{+}$progenitor cells (Fig. 6D) were not different between control and $\mathrm{IH}_{30}$. Interestingly, the proportions of $\mathrm{GFAP}^{+} / \mathrm{RFP}^{+}$astrocytes (Fig. $6 E$ ) were also unchanged by $\mathrm{IH}_{30}$. However, $\mathrm{IH}_{30}$ reduced the percentage of $\mathrm{RFP}^{+}$neurons when compared with controls (Fig. $6 F$ ), yet Sholl analysis of a subset of neurons from control and $\mathrm{IH}_{30}$ groups revealed no differences in the complexity of the dendritic trees of birth-labeled granule neurons (Fig. 6G; control group, $n=7$ neurons; $\mathrm{IH}_{30}$ group, $n=10$ neurons).
MnTMPyP treatment mitigates the suppressive effects of $\mathrm{IH}_{30}$ on adult neurogenesis and synaptic plasticity

Increasing evidence suggests that $\mathrm{IH}$ causes an increase in ROS signaling throughout the nervous system that can be mitigated by antioxidant treatment (Row et al., 2003; Ramanathan et al., 2005; Garcia et al., 2013; Snyder et al., 2017). Therefore, to determine the involvement of ROS, the superoxide anion scavenger MnT$\mathrm{MPyP}$ was administered to subjects during $\mathrm{IH}_{30}\left(\mathrm{IH}_{\text {MnTMPyP }}\right)$, and to control subjects for $30 \mathrm{~d}$ ( control $\left._{\text {MnTMPyP }}\right)$. We examined the proportion of proliferating Sox $2^{+}$cells throughout the dentate gyrus (Fig. $7 A$; control, $n=5 ; \mathrm{IH}_{30}, n=6$ ). Following $\mathrm{IH}_{\text {MnTMPyP }}$, the percentage of $\mathrm{Ki} 7^{+} / \mathrm{Sox} 2^{+}$-colabeled cells in the SGZ was elevated by $46.84 \%$ (Fig. $7 B$ ) when compared with

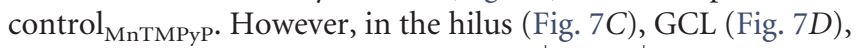
and ML (Fig. 7E) the proportion of $\mathrm{Ki} 7^{+} /$Sox $2^{+}$-colabeled cells were not different between control $_{\mathrm{MnTMPyP}}$ and $\mathrm{IH}_{\mathrm{MnTMPyP}}$ groups. These findings suggest that $\mathrm{IH}$ stimulates Sox $2{ }^{+}$cell proliferation in the hilus through an ROS-dependent process, yet in the SGZ proliferation of Sox $2^{+}$cells by $\mathrm{IH}_{30}$ was an ROSindependent phenomenon.

The $\mathrm{DCX}^{+}$immature neuronal population was no longer suppressed following $\mathrm{IH}_{\mathrm{MnTMPyP}}$ when compared with controlMnTMPyP (Fig. $8 B ; n=6$ vs $n=4$, respectively). Similarly, no changes were observed in the ratio of birth-labeled granule neu-

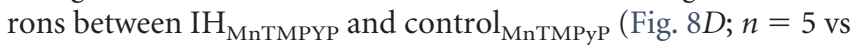
$n=6$, respectively). Thus, these findings indicate that ROS signaling contributes to the reduction in $\mathrm{DCX}^{+}$immature neurons and reduced generation of adult-born neurons caused by $\mathrm{IH}_{30}$. 
We further tested the efficacy of MnT$\mathrm{MPyP}$ to prevent the IH-dependent suppression of LTP. In the $\mathrm{IH}_{\text {MnTMPyP }}$ group, tetanic stimulation was able to evoke LTP in the dentate gyrus (Fig. 9A) and lasted up to 60 min post-HFS (Fig. $9 B ; n=6$ ). These data indicate that the generation of ROS under $\mathrm{IH}_{30}$ contributes to deficiencies in synaptic plasticity.

\section{Discussion}

Although several reports have described biochemical and neurophysiological changes occurring in the hippocampus (Row et al., 2003; Kumar et al., 2009; Xie et al., 2010; Wall et al., 2014; Yagishita et al., 2017), the impact of IH on the dentate gyrus of the hippocampus has been largely been unaddressed. Here we address this issue by examining how IH affects synaptic plasticity and adult neurogenesis in the dentate gyrus. We observed the following: (1) IH suppresses LTP in a duration-dependent manner; (2) IH impacts multiple stages of hippocampal adult neurogenesis, which ultimately results in reduction in the generation of adult-born neurons; and (3) antioxidant treatment mitigates the suppression LTP and reduced neurogenesis caused by IH. The consequences of these observations are discussed further below.

Seven days of IH does not impact LTP in the dentate gyrus (Wall et al., 2014). Similarly, we observed that LTP in the dentate gyrus is unaffected by $\mathrm{IH}_{10}$. However, increasing $\mathrm{IH}$ exposure to 20 or $30 \mathrm{~d}$ led to the attenuation of LTP. Snyder et al. (2017) recently reported that IH causes oxidative stress in the entorhinal cortex, the origin of the presynaptic fibers innervating the dentate gyrus. This raised the possibility that $\mathrm{IH}_{20}$ and $\mathrm{IH}_{30}$ impaired LTP by decreasing presynaptic excitability and/or affecting presynaptic release probability. Increasing the stimulation current during HFS, to compensate for potential reduced presynaptic excitability, however, failed to evoke LTP following $\mathrm{IH}_{30}$. Additionally, we did not observe a change in paired-pulse facilitation before or following tetanic stimulation and indicated that presynaptic release probability was unaffected by $\mathrm{IH}_{30}$. Thus, while $\mathrm{IH}$ may impact neurons of the entorhinal cortex, our observations suggest that IH-impaired LTP is derived primarily from changes in postsynaptic plasticity.

The dentate gyrus is composed of principal neurons heterogeneous in relative age, a feature that appears to contribute to the circuit properties of this network (Snyder et al., 2001). Immature granule cells derived from adult neurogenesis (i.e., $<40 \mathrm{~d}$ old) are more intrinsically excitable (Schmidt-Hieber et al., 2004) and receive less synaptic inhibition when compared with mature granule cells (i.e., $>60$ d old; Schmidt-Hieber et al., 2004; Ge et al., 2007; Gu et al., 2012a). Immature granule cells preferentially incorporate into circuits supporting spatial memory (Kee et al., 2007), and changes in the generation of immature granule cells correlate with the strength of LTP within the dentate gyrus (Park et al., 2015). Thus, alterations in adult neurogenesis would be predicted to cause significant functional remodeling of the den- tate gyrus circuitry within a 3-4 week timeframe. Indeed, we observed weakened LTP following both $\mathrm{IH}_{20}$ and $\mathrm{IH}_{30}$. Decreased neurogenesis also correlated with attenuated LTP following $\mathrm{IH}_{30}$, and by mitigating the effects of $\mathrm{IH}_{30}$ on neurogenesis via antioxidant treatment, we were able to preserve LTP. These observations support the general notion that a positive relationship exists between the strength of synaptic plasticity and adult neurogenesis and that IH negatively impairs neurophysiology in the dentate by reducing the number of adult-born neurons.

We observed that MnTMPyP administration during IH protected against both the attenuation of LTP and the reduction of neurons generated by adult neurogenesis, suggesting a role for IH-dependent ROS signaling. IH-dependent oxidative stress throughout the nervous system has been demonstrated by multiple studies (Row et al., 2003; Ramanathan et al., 2005; Garcia et al., 2013), including the dentate gyrus (Snyder et al., 2017). ROS signaling is an important factor that affects the efficacy of the synaptic plasticity. While endogenous superoxide anions may stimulate LTP via PKC signaling (Klann et al., 1998), hydrogen peroxide modulates the strength of synaptic plasticity in a concentration-dependent manner (Kamsler and Segal, 2003). Hydrogen peroxide also appears to be an important factor for proliferation and neuronal differentiation of stem cells (Dickinson et al., 2011; Forsberg et al., 2013), yet oxidative stress may also trigger apoptosis in intermediate progenitors and neuroblasts of 
the SGZ (Chatzi et al., 2015). Thus, our findings suggest that $\mathrm{IH}$-mediated effects on the dentate gyrus likely involve ROSmediated signaling and oxidative stress to suppress LTP and adult neurogenesis.

IH-mediated oxidative stress can be generated through multiple mechanisms. IH-mediated signaling via hypoxia-inducible factor 1a has been implicated to cause oxidative stress in the hippocampus (Chou et al., 2013). Similarly, prolonged IH can lead to cytokine elevations and long-term microglial changes in the hippocampus (Sapin et al., 2015) that may cause oxidative stress. These pathways may act uniquely on adult neurogenesis but not affect synaptic plasticity or vice versa. Therefore, while it will be critical to examine the basis for IH-dependent ROS signaling in both LTP and adult neurogenesis, understanding how IH may disrupt synaptic plasticity through mechanisms unrelated to adult neurogenesis, such as changes to the electrophysiological properties of mature granule neurons, activation of glial cells, and inflammation, will be important.

In agreement with previous investigations (Gozal et al., 2003; Pedroso et al., 2016), we find that the Sox $2^{+}$neural progenitor cell population increased with IH exposure. However, while Gozal et al. (2003) concluded that IH promotes the generation of adult-born neurons, Pedroso et al. (2016) reported that IH negatively impacts the generation of adult-born neurons. We observed that $\mathrm{IH}$ causes a reduction in $\mathrm{DCX}^{+}$neurons. Our approach to label a discrete population of Nestin ${ }^{+}$neural progenitor cells also provided substantial resolution for understanding how IH affects a single cycle of neurogenesis $(\sim 28 \mathrm{~d})$ not achieved with prior studies. Consistent with the observed proliferation in Sox $2^{+}$cells, IH increased the proportion of birthlabeled $\mathrm{RFP}^{+} / \mathrm{GFAP}^{+}$neural progenitor cells with radial glial morphology in the SGZ. In contrast, the proportion of granule neurons generated from the discretely labeled neural progenitor population was reduced and agreed with the observation that $\mathrm{IH}_{30}$ reduced DCX ${ }^{+}$neurons. The ability for MnTMPyP to mitigate the impact of $\mathrm{IH}$ on birth-labeled neurons following $\mathrm{IH}_{30}$ further indicate that enhanced ROS signaling, presumably through oxidative stress, causes cell death in late progenitors transitioning to immature neurons or in the immature neurons themselves.

We also observed that Sox $2^{+}$cell proliferation occurred in the SGZ and hilus. The increased mitotic activity appeared to be differentially affected by antioxidant treatment during IH. Sox $2^{+}$ cell proliferation in the hilus presumably represented increased glial expansion (Komitova and Eriksson, 2004; Brazel et al., 2005). Hilar expansion of SOX ${ }^{+}$cells was prevented by MnTMPyP; whereas, in the SGZ, IH-induced expansion of Sox $2^{+}$ neural progenitor cells was unaffected by antioxidant treatment. Thus, while IH may stimulate glial proliferation via an ROSdependent mechanism, Sox $2^{+}$neural progenitor cell proliferation appears to be ROS independent. Hypoxia itself may be one potential factor causing stimulation of neural progenitor cell proliferation. Despite the brevity of a single bout of hypoxia ( $<30 \mathrm{~s}$ at the $5 \% \mathrm{O}_{2}$ nadir), the repeated hypoxic stimuli may be sufficient to promote the proliferation of the neural progenitor cell pool, as neural progenitor cells normally exist in hypoxic niches of the SGZ (Chatzi et al., 2015). Additionally, neural progenitors increase proliferation under mild hypoxic conditions (Studer et al., 2000; Santilli et al., 2010). Although we did not examine the long-term consequence of the $\mathrm{IH}$-dependent expansion of the neural progenitor cell population, growing evidence suggests that the pool of neural progenitor cells in the hippocampus is finite (Kippin et al., 2005; Furutachi et al., 2013; Ottone et al., 2014).
Therefore, IH-dependent expansion of the neural progenitor population may accelerate depletion of the pool, leading to reductions in the number of neurons generated by future cycles of neurogenesis, even if $\mathrm{IH}$ is no longer experienced.

In conclusion, our study provides key insights into the duration-dependent effects of IH on synaptic plasticity in the dentate gyrus. The impairment of synaptic plasticity was accompanied by reduced adult neurogenesis. Thus, the IH-mediated changes observed here suggest that sleep apnea may be a condition that dictates the outcome of hippocampal adult neurogenesis and synaptic plasticity. These changes may ultimately contribute to decline in neurocognitive behaviors and injury in the hippocampus when left untreated or undetected.

\section{References}

Arendt A, Böttger G, Lehmann J (1983) Loss of neurons in the granular layer of the cerebellum in epilepsy (in German). Zentralblatt fur Allg Pathol u Pathol Anat 128:351-355.

Bartesaghi R, Guidi S, Ciani E (2011) Is it possible to improve neurodevelopmental abnormalities in Down syndrome? Rev Neurosci 22:419-455. CrossRef Medline

Beebe DW, Gozal D (2002) Obstructive sleep apnea and the prefrontal cortex: towards a comprehensive model linking nocturnal upper airway obstruction to daytime cognitive and behavioral deficits. J Sleep Res 11:1-16. CrossRef Medline

Brazel CY, Limke TL, Osborne JK, Miura T, Cai J, Pevny L, Rao MS (2005) Sox2 expression defines a heterogeneous population of neurosphereforming cells in the adult murine brain. Aging Cell 4:197-207. CrossRef Medline

Bruel-Jungerman E, Laroche S, Rampon C (2005) New neurons in the dentate gyrus are involved in the expression of enhanced long-term memory following environmental enrichment. Eur J Neurosci 21:513-521. CrossRef Medline

Canessa N, Castronovo V, Cappa SF, Aloia MS, Marelli S, Falini A, Alemanno F, Ferini-Strambi L (2011) Obstructive sleep apnea: brain structural changes and neurocognitive function before and after treatment. Am J Respir Crit Care Med 183:1419-1426. CrossRef Medline

Castronovo V, Canessa N, Strambi LF, Aloia MS, Consonni M, Marelli S, Iadanza A, Bruschi A, Falini A, Cappa SF (2009) Brain activation changes before and after PAP treatment in obstructive sleep apnea. Sleep 32:1161-1172. CrossRef Medline

Cha J, Zea-Hernandez JA, Sin S, Graw-Panzer K, Shifteh K, Isasi CR, Wagshul ME, Moran EE, Posner J, Zimmerman ME, Arens R (2017) The effects of obstructive sleep apnea syndrome on the dentate gyrus and learning and memory in children. J Neurosci 37:4280-4288. CrossRef Medline

Chatzi C, Schnell E, Westbrook GL (2015) Localized hypoxia within the subgranular zone determines the early survival of newborn hippocampal granule cells. Elife 4:e08722. CrossRef Medline

Chou YT, Zhan G, Zhu Y, Fenik P, Panossian L, Li Y, Zhang J, Veasey S (2013) C/EBP homologous binding protein (CHOP) underlies neural injury in sleep apnea model. Sleep 36:481-492. CrossRef Medline

De Filippis L, Delia D (2011) Hypoxia in the regulation of neural stem cells. Cell Mol Life Sci 68:2831-2844. CrossRef Medline

Dickinson BC, Peltier J, Stone D, Schaffer DV, Chang CJ (2011) Nox2 redox signaling maintains essential cell populations in the brain. Nat Chem Biol 7:106-112. CrossRef Medline

Forsberg K, Wuttke A, Quadrato G, Chumakov PM, Wizenmann A, Di Giovanni S (2013) The tumor suppressor p53 fine-tunes reactive oxygen species levels and neurogenesis via PI3 kinase signaling. J Neurosci 33: 14318-14330. CrossRef Medline

Furutachi S, Matsumoto A, Nakayama KI, Gotoh Y (2013) p57 controls adult neural stem cell quiescence and modulates the pace of lifelong neurogenesis. EMBO J 32:970-981. CrossRef Medline

Garcia AJ 3rd, Rotem-Kohavi N, Doi A, Ramirez JM (2013) Post-hypoxic recovery of respiratory rhythm generation is gender dependent. PLoS One 8:e60695. CrossRef Medline

Garcia AJ 3rd, Zanella S, Dashevskiy T, Khan SA, Khuu MA, Prabhakar NR, Ramirez JM (2016) Chronic intermittent hypoxia alters local respiratory circuit function at the level of the preBötzinger complex. Front Neurosci 10:4. CrossRef Medline 
Ge S, Yang CH, Hsu KS, Ming GL, Song H (2007) A critical period for enhanced synaptic plasticity in newly generated neurons of the adult brain. Neuron 54:559-566. CrossRef Medline

Gozal D, Daniel JM, Dohanich GP (2001) Behavioral and anatomical correlates of chronic episodic hypoxia during sleep in the rat. J Neurosci 21:2442-2450. CrossRef Medline

Gozal D, Row BW, Gozal E, Kheirandish L, Neville JJ, Brittian KR, Sachleben LR Jr, Guo SZ (2003) Temporal aspects of spatial task performance during intermittent hypoxia in the rat: evidence for neurogenesis. Eur J Neurosci 18:2335-2342. CrossRef Medline

Gu Y, Arruda-Carvalho M, Wang J, Janoschka SR, Josselyn SA, Frankland PW, Ge S (2012a) Optical controlling reveals time-dependent roles for adult-born dentate granule cells. Nat Neurosci 15:1700-1706. CrossRef Medline

Gu Z, Lamb PW, Yakel JL (2012b) Cholinergic coordination of presynaptic and postsynaptic activity induces timing-dependent hippocampal synaptic plasticity. J Neurosci 32:12337-12348. CrossRef Medline

Hodge RD, Kowalczyk TD, Wolf SA, Encinas JM, Rippey C, Enikolopov G, Kempermann G, Hevner RF (2008) Intermediate progenitors in adult hippocampal neurogenesis: Tbr2 expression and coordinate regulation of neuronal output. J Neurosci 28:3707-3717. CrossRef Medline

Hodge RD, Nelson BR, Kahoud RJ, Yang R, Mussar KE, Reiner SL, Hevner RF (2012) Tbr2 is essential for hippocampal lineage progression from neural stem cells to intermediate progenitors and neurons. J Neurosci 32:62756287. CrossRef Medline

Imayoshi I, Ohtsuka T, Metzger D, Chambon P, Kageyama R (2006) Temporal regulation of cre recombinase activity in neural stem cells. Genesis 44:233-238. CrossRef Medline

Jackson ML, Howard ME, Barnes M (2011) Cognition and daytime functioning in sleep-related breathing disorders. Prog Brain Res 190:53-68. CrossRef Medline

Kamsler A, Segal M (2003) Hydrogen peroxide modulation of synaptic plasticity. J Neurosci 23:269-276. CrossRef Medline

Kee N, Teixeira CM, Wang AH, Frankland PW (2007) Preferential incorporation of adult-generated granule cells into spatial memory networks in the dentate gyrus. Nat Neurosci 10:355-362. CrossRef Medline

Kippin TE, Martens DJ, van der Kooy D (2005) p21 loss compromises the relative quiescence of forebrain stem cell proliferation leading to exhaustion of their proliferation capacity. Genes Dev 19:756-767. CrossRef Medline

Klann E, Roberson ED, Knapp LT, Sweatt JD (1998) A role for superoxide in protein kinase $\mathrm{C}$ activation and induction of long-term potentiation. J Biol Chem 273:4516-4522. CrossRef Medline

Komitova M, Eriksson PS (2004) Sox-2 is expressed by neural progenitors and astroglia in the adult rat brain Neurosci Lett 369:24-27. CrossRef Medline

Kumar R, Macey PM, Cross RL, Woo MA, Yan-Go FL, Harper RM (2009) Neural alterations associated with anxiety symptoms in obstructive sleep apnea syndrome. Depress Anxiety 26:480-491. CrossRef Medline

Leng Y, McEvoy CT, Allen IE, Yaffe K (2017) Association of sleepdisordered breathing with cognitive function and risk of cognitive impairment: a systematic review and meta-analysis. JAMA Neurol 74: 1237-1245. CrossRef Medline

Li B, Yamamori H, Tatebayashi Y, Shafit-Zagardo B, Tanimukai H, Chen S, Iqbal K, Grundke-Iqbal I (2008) Failure of neuronal maturation in Alzheimer disease dentate gyrus. J Neuropathol Exp Neurol 67:78-84. CrossRef Medline

Malhotra A, White DP (2002) Obstructive sleep apnoea. Lancet 360:237245. CrossRef Medline

Maski K, Steinhart E, Holbrook H, Katz ES, Kapur K, Stickgold R (2017) Impaired memory consolidation in children with obstructive sleep disordered breathing. PLoS One 12:e0186915. CrossRef Medline

Mazumdar J, O’Brien WT, Johnson RS, LaManna JC, Chavez JC, Klein PS, Simon MC (2010) O2 regulates stem cells through Wnt $/ \beta$-catenin signalling. Nat Cell Biol 12:1007-1013. CrossRef Medline

Miller JA, Nathanson J, Franjic D, Shim S, Dalley RA, Shapouri S, Smith KA, Sunkin SM, Bernard A, Bennett JL, Lee CK, Hawrylycz MJ, Jones AR, Amaral DG, Šestan N, Gage FH, Lein ES (2013) Conserved molecular signatures of neurogenesis in the hippocampal subgranular zone of rodents and primates. Development 140:4633-4644. CrossRef Medline
Morrell MJ, McRobbie DW, Quest RA, Cummin AR, Ghiassi R, Corfield DR (2003) Changes in brain morphology associated with obstructive sleep apnea. Sleep Med 4:451-454. CrossRef Medline

Ottone C, Krusche B, Whitby A, Clements M, Quadrato G, Pitulescu ME, Adams RH, Parrinello S (2014) Direct cell-cell contact with the vascular niche maintains quiescent neural stem cells. Nat Cell Biol 16:1045-1056. CrossRef Medline

Panchision DM (2009) The role of oxygen in regulating neural stem cells in development and disease. J Cell Physiol 220:562-568. CrossRef Medline

Park EH, Burghardt NS, Dvorak D, Hen R, Fenton AA (2015) Experiencedependent regulation of dentate gyrus excitability by adult-born granule cells. J Neurosci 35:11656-11666. CrossRef Medline

Pedroso D, Nunes AR, Diogo LN, Oudot C, Monteiro EC, Brenner C, Vieira HLA (2016) Hippocampal neurogenesis response: what can we expect from two different models of hypertension? Brain Res 1646:199-206. CrossRef Medline

Polotsky VY, Rubin AE, Balbir A, Dean T, Smith PL, Schwartz AR, O’Donnell CP (2006) Intermittent hypoxia causes REM sleep deficits and decreases EEG delta power in NREM sleep in the C57BL/6J mouse. Sleep Med 7:7-16. CrossRef Medline

Prakash YS, Smithson KG, Sieck GC (1994) Application of the Cavalieri principle in volume estimation using laser confocal microscopy. Neuroimage 1:325-333. CrossRef Medline

Ramanathan L, Gozal D, Siegel JM (2005) Antioxidant responses to chronic hypoxia in the rat cerebellum and pons. J Neurochem 93:47-52. CrossRef Medline

Rosen GD, Harry JD (1990) Brain volume estimation from serial section measurements: a comparison of methodologies. J Neurosci Methods 35: 115-124. CrossRef Medline

Row BW, Liu R, Xu W, Kheirandish L, Gozal D (2003) Intermittent hypoxia is associated with oxidative stress and spatial learning deficits in the rat. Am J Respir Crit Care Med 167:1548-1553. CrossRef Medline

Santilli G, Lamorte G, Carlessi L, Ferrari D, Rota Nodari L, Binda E, Delia D, Vescovi AL, De Filippis L (2010) Mild hypoxia enhances proliferation and multipotency of human neural stem cells. PLoS One 5:e8575. CrossRef Medline

Sapin E, Peyron C, Roche F, Gay N, Carcenac C, Savasta M, Levy P, Dematteis M (2015) Chronic intermittent hypoxia induces chronic low-grade neuroinflammation in the dorsal hippocampal of mice. Sleep 38:1537-1546. CrossRef Medline

Schindelin J, Arganda-Carreras I, Frise E, Kaynig V, Longair M, Pietzsch T, Preibisch S, Rueden C, Saalfeld S, Schmid B, Tinevez JY, White DJ, Hartenstein V, Eliceiri K, Tomancak P, Cardona A (2012) Fiji: an opensource platform for biological-image analysis. Nat Methods 9:676-682. CrossRef Medline

Schmidt-Hieber C, Jonas P, Bischofberger J (2004) Enhanced synaptic plasticity in newly generated granule cells of the adult hippocampus. Nature 429:184-187. CrossRef Medline

Schneider CA, Rasband WS, Eliceiri KW (2012) NIH image to ImageJ: 25 years of image analysis. Nat Methods 9:671-675. CrossRef Medline

Schröder CM, O’Hara R (2005) Depression and Obstructive Sleep Apnea (OSA). Ann Gen Psychiatry 4:13. CrossRef Medline

Sforza E, Roche F (2012) Sleep apnea syndrome and cognition. Front Neurol 3:87. CrossRef Medline

Snyder B, Shell B, Cunningham JT, Cunningham RL (2017) Chronic intermittent hypoxia induces oxidative stress and inflammation in brain regions associated with early-stage neurodegeneration. Physiol Rep 5:e13258. CrossRef Medline

Snyder JS, Kee N, Wojtowicz JM (2001) Effects of adult neurogenesis on synaptic plasticity in the rat dentate gyrus. J Neurophysiol 85:2423-2431. CrossRef Medline

Studer L, Csete M, Lee SH, Kabbani N, Walikonis J, Wold B, McKay R (2000) Enhanced proliferation, survival, and dopaminergic differentiation of CNS precursors in lowered oxygen. J Neurosci 20:7377-7383. CrossRef Medline

Tan HL, Gozal D, Kheirandish-Gozal L (2013) Obstructive sleep apnea in children: a critical update. Nat Sci Sleep 5:109-123. CrossRef Medline

Tashiro A, Makino H, Gage FH (2007) Experience-specific functional modification of the dentate gyrus through adult neurogenesis: a critical period during an immature stage. J Neurosci 27:3252-3259. CrossRef Medline 
Torelli F, Moscufo N, Garreffa G, Placidi F, Romigi A, Zannino S, Bozzali M, Fasano F, Giulietti G, Djonlagic I, Malhotra A, Marciani MG, Guttmann CR (2011) Cognitive profile and brain morphological changes in obstructive sleep apnea. Neuroimage 54:787-793. CrossRef Medline

van Praag H, Kempermann G, Gage FH (1999) Running increases cell proliferation and neurogenesis in the adult mouse dentate gyrus. Nat Neurosci 2:266-270. CrossRef Medline

Wall AM, Corcoran AE, O'Halloran KD, O'Connor JJ (2014) Effects of prolyl-hydroxylase inhibition and chronic intermittent hypoxia on synaptic transmission and plasticity in the rat CAl and dentate gyrus. Neurobiol Dis 62:8-17. CrossRef Medline

Xie H, Leung KL, Chen L, Chan YS, Ng PC, Fok TF, Wing YK, Ke Y, Li AM, Yung WH (2010) Brain-derived neurotrophic factor rescues and prevents chronic intermittent hypoxia-induced impairment of hippocampal long-term synaptic plasticity. Neurobiol Dis 40:155-162. CrossRef Medline

Yagishita S, Suzuki S, Yoshikawa K, Iida K, Hirata A, Suzuki M, Takashima A, Maruyama K, Hirasawa A, Awaji T (2017) Treatment of intermittent hypoxia increases phosphorylated tau in the hippocampus via biological processes common to aging. Mol Brain 10:2. CrossRef Medline

Young T, Palta M, Dempsey J, Peppard PE, Nieto FJ, Hla KM (2009) Burden of sleep apnea: rationale, design, and major findings of the Wisconsin Sleep Cohort study. WMJ 108:246-249. Medline

Yuan X, Guo X, Deng Y, Zhu D, Shang J, Liu H (2015) Chronic intermittent hypoxia-induced neuronal apoptosis in the hippocampus is attenuated by telmisartan through suppression of iNOS/NO and inhibition of lipid peroxidation and inflammatory responses. Brain Res 1596:48-57. CrossRef Medline 